\title{
Seismic Shear Wave Reflection Imaging at the Former Fort Ord, Monterey, California
}

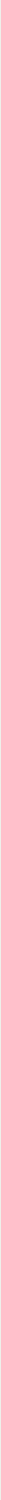




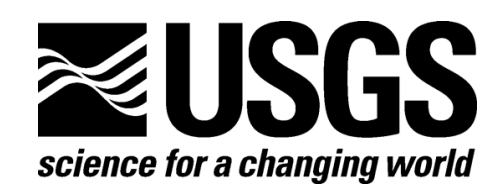

In cooperation with the U.S. Army Corps of Engineers

\section{Seismic Shear Wave Reflection Imaging at the Former Fort Ord, Monterey, California}

By Seth S. Haines, Bethany L. Burton, and Lewis E. Hunter

Open-File Report 2007-1068

U.S. Department of the Interior

U.S. Geological Survey 


\title{
U.S. Department of the Interior DIRK KEMPTHORNE, Secretary
}

\author{
U.S. Geological Survey \\ Mark D. Myers, Director
}

U.S. Geological Survey, Reston, Virginia 2007

For product and ordering information:

World Wide Web: http://www.usgs.gov/pubprod

Telephone: 1-888-ASK-USGS

For more information on the USGS - the Federal source for science about the Earth, its natural and living resources, natural hazards, and the environment:

World Wide Web: http://www.usgs.gov

Telephone: 1-888-ASK-USGS

Suggested citation:

Haines, S.S., Burton, B.L., and Hunter, L.E., 2007, Seismic shear wave reflection imaging at the former Fort Ord, Monterey, California: U.S. Geological Survey Open-File Report 2007-1068, 13 p., available only online at http://pubs.usgs.gov/of/2007/1068/.

Any use of trade, product, or firm names is for descriptive purposes only and does not imply endorsement by the U.S. Government.

Although this report is in the public domain, permission must be secured from the individual copyright owners to reproduce any copyrighted material contained within this report. 


\section{Contents}

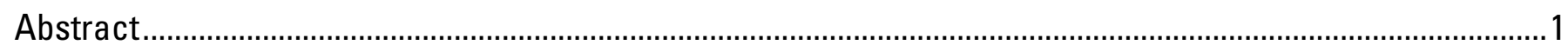

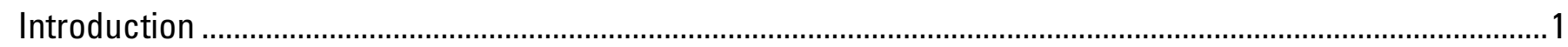

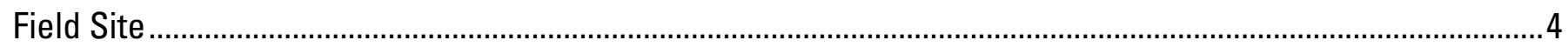

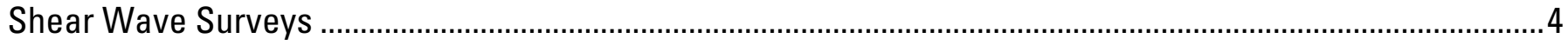

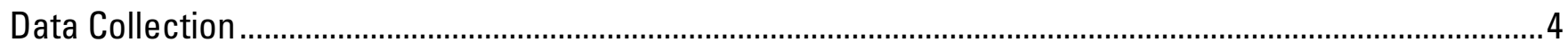

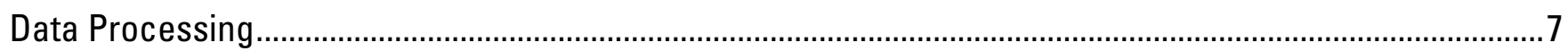

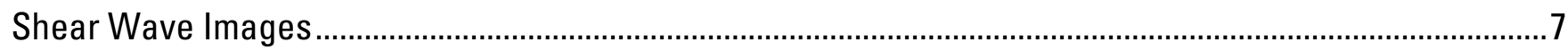

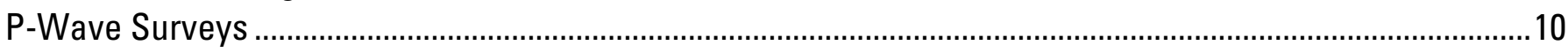

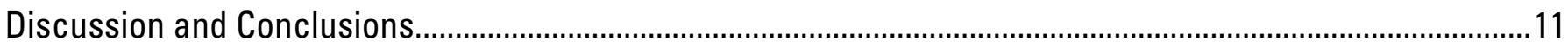

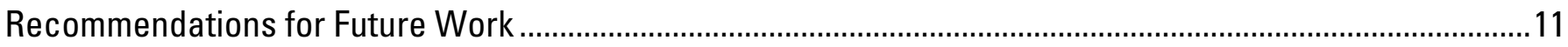

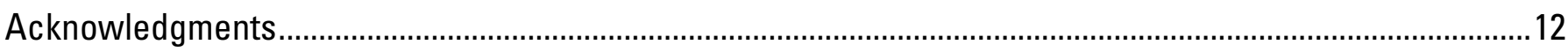

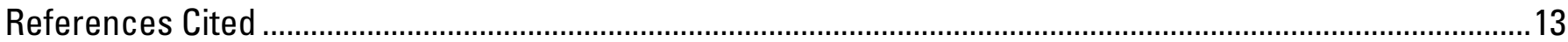

\section{Conversion Factors}

\begin{tabular}{lll}
\hline \multicolumn{1}{r}{ Multiply } & \multicolumn{1}{c}{ By } & \multicolumn{1}{c}{ To obtain } \\
\hline foot $(\mathrm{ft})$ & 0.3048 & meter $(\mathrm{m})$ \\
foot per second $(\mathrm{ft} / \mathrm{s})$ & 0.3048 & meter per second $(\mathrm{m} / \mathrm{s})$ \\
meter $(\mathrm{m})$ & 3.281 & foot $(\mathrm{ft})$ \\
meter per second $(\mathrm{m} / \mathrm{s})$ & 3.281 & foot per second $(\mathrm{ft} / \mathrm{s})$ \\
\hline
\end{tabular}

Vertical coordinate information is referenced to the North American Vertical Datum of 1988 (NAVD 88).

Horizontal coordinate information is referenced to the North American Datum of 1983 (NAD 83).

Altitude, as used in this report, refers to distance above the vertical datum. 


\title{
Seismic Shear Wave Reflection Imaging at the Former Fort Ord, Monterey, California
}

\author{
By Seth S. Haines, Bethany L. Burton, and Lewis E. Hunter
}

\begin{abstract}
At the former Fort Ord in Monterey County, California, contamination threatens an aquifer that provides drinking water for local communities. Assessment and remediation require accurate hydrological modeling, which in turn require a thorough understanding of aquifer stratigraphy. In order to help guide remediation efforts at the site, the U.S. Geological Survey, in cooperation with the U.S. Army Corps of Engineers, has undertaken seismic reflection surveys, testing compressional $(\mathrm{P})$ and horizontally polarized shear (SH) waves. Sledgehammer-source $\mathrm{SH}$ data show reflections from interfaces up to approximately $60 \mathrm{~m}$ deep, which correspond with the major boundaries between aquifers and aquitards. In contrast, P-wave data show only the reflection from the water table at approximately $30 \mathrm{~m}$ depth. We collected SH data along two transects and processed these data to produce reflection images. The interpreted $\mathrm{SH}$-wave images agree with available well information, constrain the geology for ground-water models, and provide guidance for future geophysical studies. These favorable results demonstrate the effectiveness of SH reflection methods for imaging unconsolidated aquifer layers at the former Fort Ord and at other sites with similar geologic conditions.
\end{abstract}

\section{Introduction}

The former Fort Ord (fig. 1) is located approximately $9 \mathrm{~km}$ north of Monterey, Calif., and has been listed on the National Priorities List of the Superfund program since 1990 (http://www.epa.gov/superfund/sites/npl/ca.htm). Originally operating as a training and staging facility, the Fort opened in 1917 and served various purposes before its 1991 decommissioning. Like many such sites, surface disposal of cleaning solvents in the 1950's has led to subsurface contamination that threatens important ground water aquifers (MACTEC, 2005). 


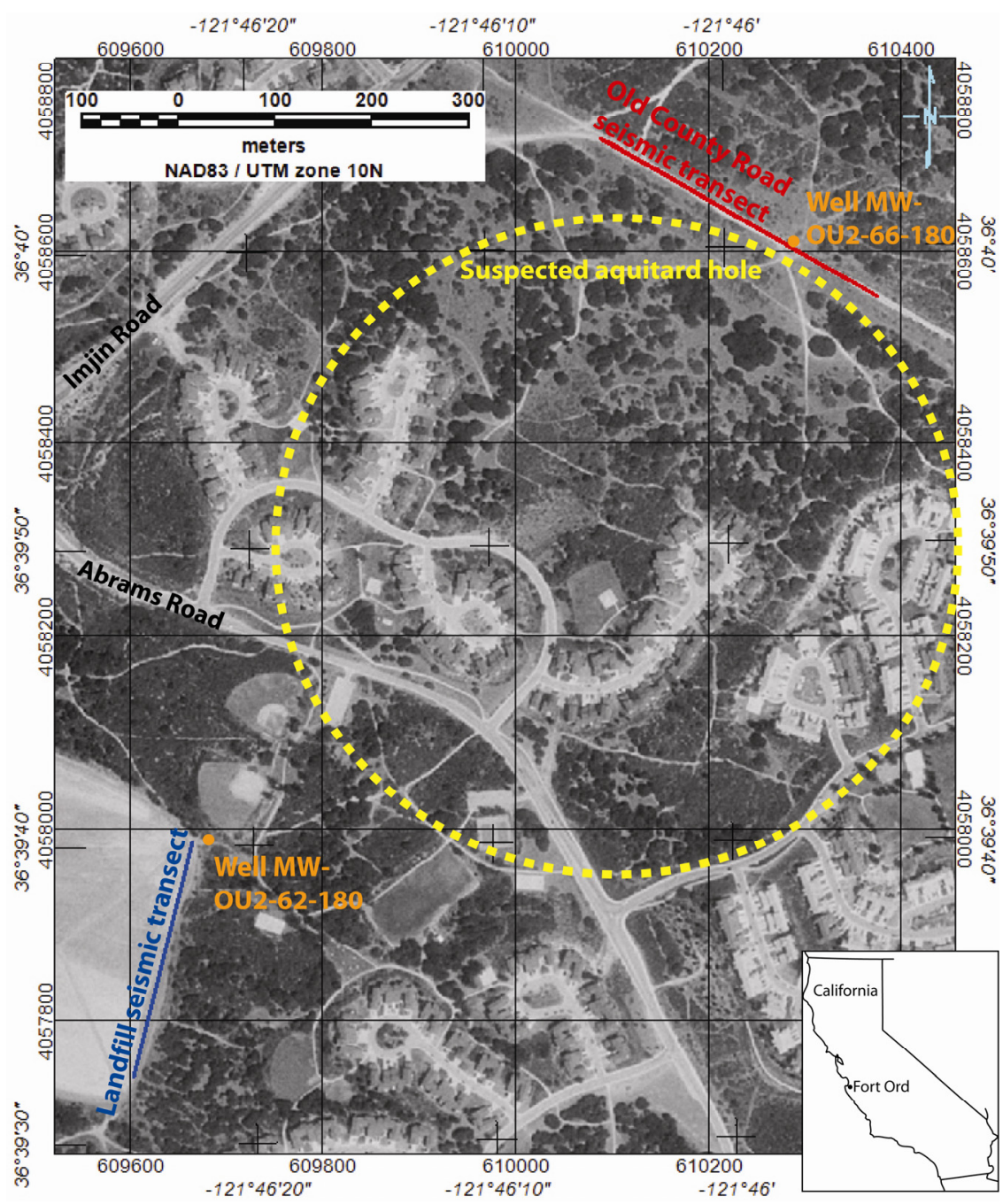

Figure 1. Air photograph of the Fort Ord site. The Old County Road seismic transect is plotted in red, and the Landfill transect in blue. The dashed yellow circle shows the approximate boundaries of the suspected hole in the Intermediate 180-Foot Aquitard.

Subsurface geology at the site is well known from borehole information (MACTEC, 2005) and is depicted in figure 2. The A aquifer is the uppermost layer and consists of approximately $35 \mathrm{~m}$ of clean dune sands. The underlying Fort Ord-Salinas Valley Aquitard (FO-SVA) consists of approximately $12 \mathrm{~m}$ of dense marine clay. The Upper 180-Foot Aquifer consists of approximately $15 \mathrm{~m}$ of mixed sand, gravel, and silt. The Intermediate 180-Foot Aquitard consists of approximately $10 \mathrm{~m}$ of silt and clay. The lowermost layer of interest in this study is the Lower 180-Foot Aquifer that consists of sand, gravel, and silt. The water table in the A Aquifer is at a depth of 25 to $35 \mathrm{~m}$, depending on location. The Upper 180-Foot Aquifer is a confined aquifer in most places, but may have localized air pockets during dry periods. The Intermediate 180-Foot Aquitard is the layer of most interest in this investigation, because borehole logs and hydrological modeling suggest that the layer is discontinuous, and that it may contain a large hole. 


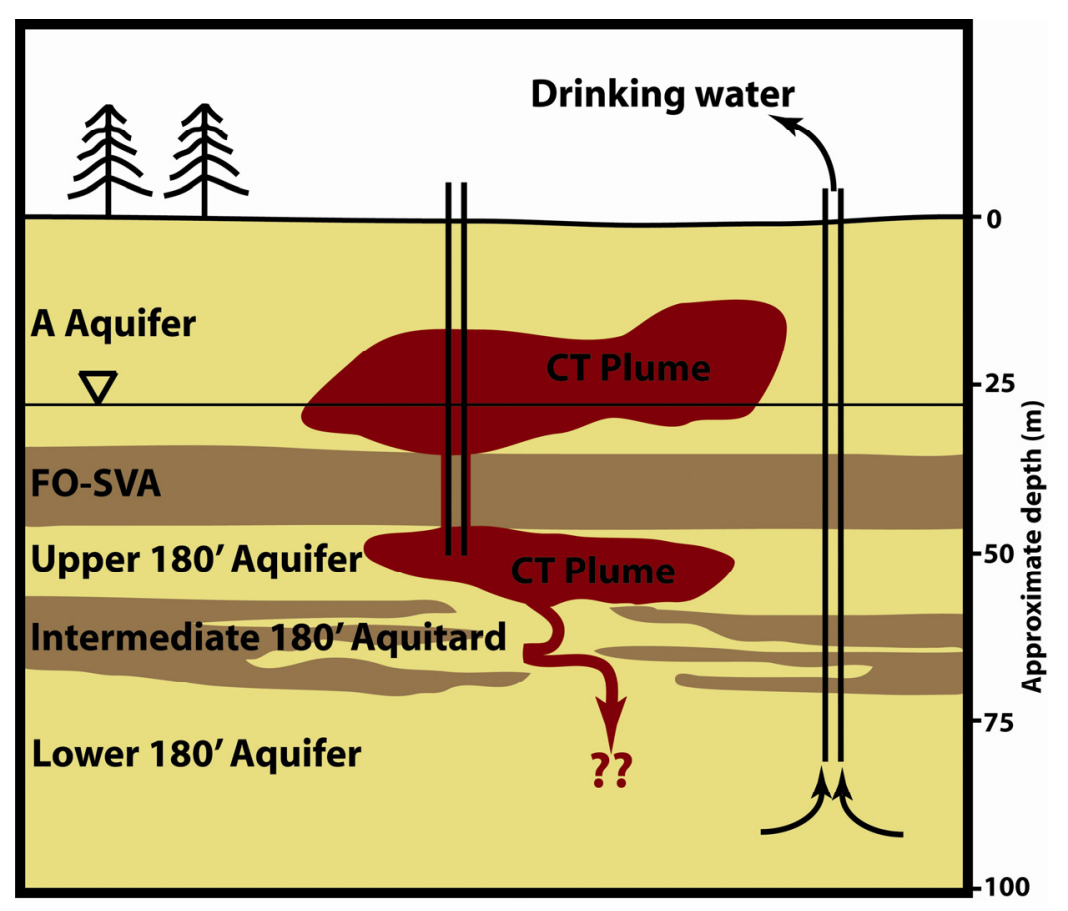

Figure 2. Schematic cross section at Fort Ord showing major aquifer units, the suspected hole in the Intermediate 180-Foot Aquitard, the A-Aquifer water table (black triangle), the Fort Ord-Salinas Valley Aquitard (FO-SVA), and a representation of the carbon tetrachloride (CT) plume that threatens the Lower 180-Foot Aquitard.

Contaminants (carbon tetrachloride (CT) and trichloroethene (TCE)) have migrated from the surface, through the A-Aquifer sands, through the FO-SVA via improperly sealed boreholes, and into the Upper 180-Foot Aquifer. The contaminants now appear to be progressing toward the Lower 180Foot Aquifer by way of the suspected hole in the Intermediate 180-Foot Aquitard. Contamination of the Lower 180-Foot Aquifer is significant because it provides drinking water for many residents of Monterey County and irrigation water for some of the Salinas Valley. Approximately 40,000 people rely on drinking water from wells that lie within $5 \mathrm{~km}$ of the site (http://www.epa.gov/superfund/sites/npl/ca.htm), making accurate characterization and effective mitigation imperative.

In order to help guide remediation efforts and to guide future geophysical studies, USGS personnel collected compressional $(\mathrm{P})$ and horizontally polarized shear $(\mathrm{SH})$ wave seismic data along two survey transects in July 2006 (fig. 1). The purpose of this pilot study was to test the feasibility of using these methods to image the Intermediate 180-Foot Aquitard. The shear wave reflection method provides good resolution of the upper aquifer layers and successfully illuminates the Intermediate 180Foot Aquitard where it is thick and coherent. However, the effectiveness of the method, as it was carried out for this study, is limited where the Intermediate 180-Foot Aquitard consists of several thin layers. The P-wave reflection method is ineffective at this site, showing only the water table and the first multiple of the water table. 


\section{Field Site}

Much of the former Fort Ord has been converted to other uses. The area of the suspected aquitard hole is now divided between student housing for California State University at Monterey Bay (the residences are visible in fig. 1) and the Fort Ord Natural Reserve, a part of the University of California Natural Reserve System (the vegetated areas shown in fig. 1). Geophysical survey work was not permitted within the Reserve area except along the Old County Road, and would have been logistically difficult in the residential area.

We conducted seismic surveys along two transects that are near to, but outside of, the suspected location of the aquitard hole (fig. 1). These transects were chosen for their proximity to the suspected aquitard hole, accessibility, and proximity to boreholes with well log information. Both transects are along dirt roads, which simplifies survey logistics and improves data quality because compacted soil reduces the amplitude of problematic Love waves (for example, Haines and Ellefsen, 2006). The Old County Road transect (fig. 1) lies northeast of the suspected aquitard hole, along the so-called "Old County Road" that is a seldom-used, one-lane, unimproved road. The survey transect is adjacent to borehole MW-OU2-66-180. The Landfill transect lies southwest of the suspected hole (fig. 1), along the unimproved road that runs north-south along the east side of the old Fort Ord landfill. Well MWOU2-62-180 is near the north end of the Landfill transect.

\section{Shear Wave Surveys}

\section{Data Collection}

A series of tests conducted along the Old County Road transect demonstrated that sledgehammer impacts on an aluminum source (Haines and Ellefsen, 2006) produce the best high-amplitude coherent reflections, and that horizontal geophones at a spacing of approximately $3 \mathrm{~m}$ are the best receiver spacing for the survey. We also tested a $90-\mathrm{kg}$ accelerated weight drop seismic source, which is configured such that impacts can be tilted 45 degrees from vertical in order to produce shear waves. Data from the weight drop are compared with sledgehammer-source data in figure 3 , and the superiority of the sledgehammer source is evident in figure $3 \mathrm{a}$, where several reflections are clearly visible. The weight drop data (fig. 3 b) show strong reverberations that obscure the reflected arrivals. 


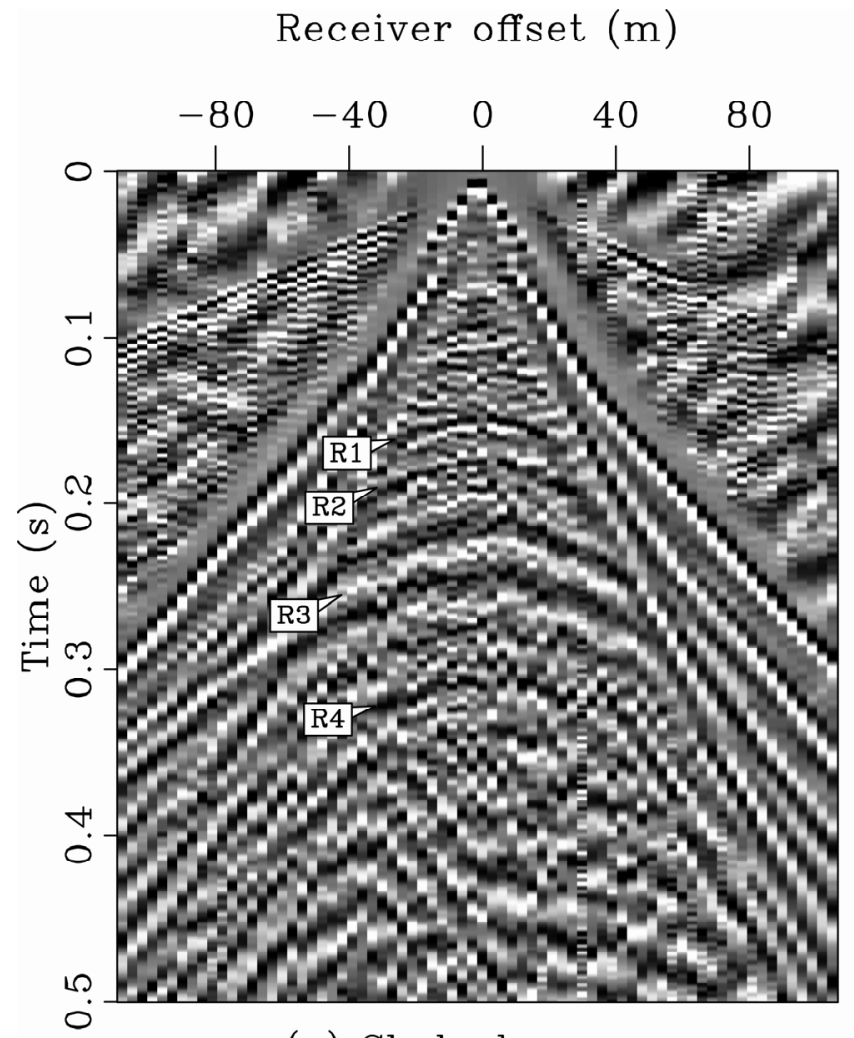

(a) Sledgehammer

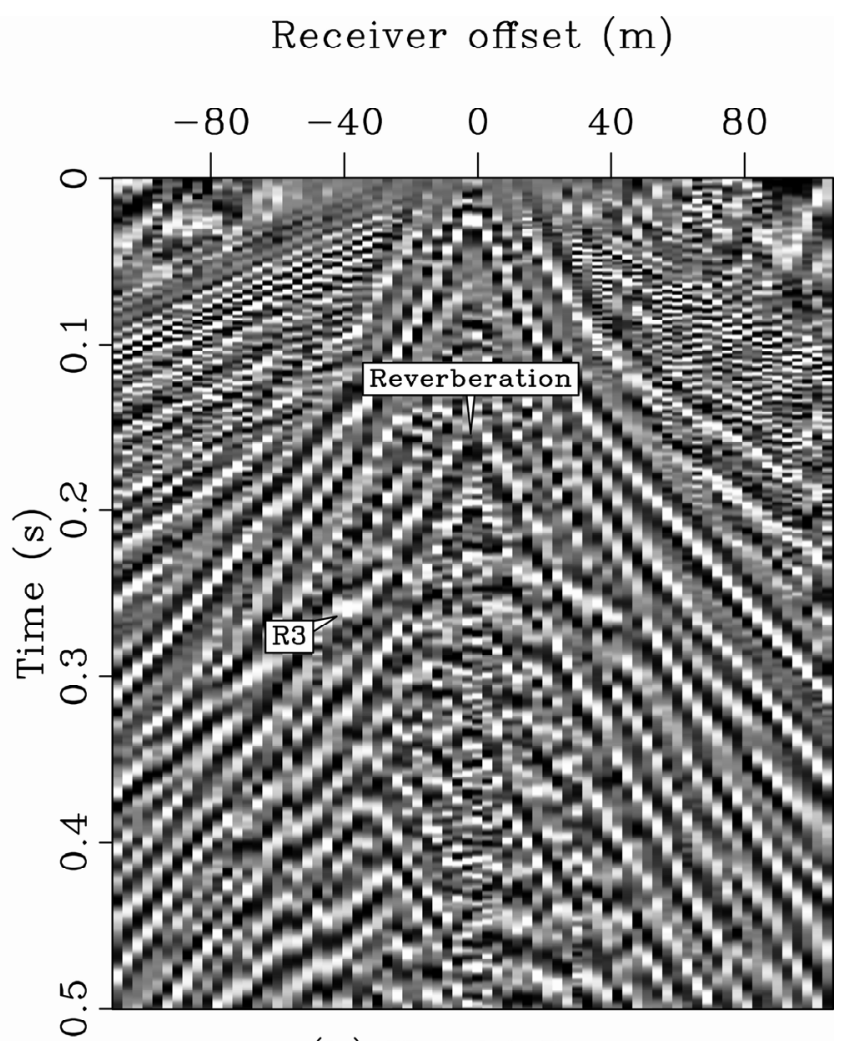

(b) Weight Drop

Figure 3. Shear wave data shot gathers from Old County Road transect. a) Data collected with the sledgehammer-source, with 4 reflections marked. $\mathrm{R} 1$ is from the top of the Fort Ord-Salinas Valley Aquitard (FO-SVA), R2 is from an interface within the FO-SVA, R3 is from the base of the FO-SVA, and R4 is from the top of the Intermediate 180-Foot Aquitard. b) Data collected with the weight drop source, with reflection R3 labeled. The other reflections are masked by the strong, reverberatory, source-related coherent noise that is labeled "Reverberation".

Impacts perpendicular to the seismic transect create $\mathrm{SH}$ waves propagating along the transect. By stacking data from opposing impacts after a polarity reversal, we minimize unwanted P- and Rayleigh-wave energy. For each shot location along each transect, we recorded four impacts, two of each polarity. We perform stacking in the office rather than in the field to enable both the rejection of noisy shots and any adjustments needed to correct trigger errors. Specific survey parameters are shown in table 1.

Table 1. Seismic data recording parameters.

\begin{tabular}{llll}
\hline & \multicolumn{1}{c}{ Old County Road Line } & Landfill Line \\
\hline Number of recording stations & 96 & 72 & $3.5 \mathrm{~m}$ \\
\hline Geophone spacing & $3 \mathrm{~m}$ & $3.5 \mathrm{~m}$ \\
\hline Shot spacing & $3 \mathrm{~m}$ & $256 \mathrm{~m}$ \\
\hline Line length & $289 \mathrm{~m}$ &
\end{tabular}




\begin{tabular}{lll}
\hline Shear wave geophones & $10-\mathrm{Hz}$ horizontal & 10-Hz horizontal \\
\hline Shear wave source & $5.4-\mathrm{kg}$ sledge on aluminum source & 5.4-kg sledge on aluminum source \\
\hline P-wave geophones & $10-\mathrm{Hz}$ and $40-\mathrm{Hz}$ vertical & $10-\mathrm{Hz}$ and $40-\mathrm{Hz}$ vertical \\
\hline P-wave source & $90-\mathrm{kg}$ accelerated weight drop & $5.4-\mathrm{kg}$ sledge on steel plate \\
\hline Record length & $1 \mathrm{~s}$ & $1 \mathrm{~s}$ \\
\hline Sample rate & $0.0005 \mathrm{~s}$ & $0.0005 \mathrm{~s}$ \\
\hline
\end{tabular}

A representative shear wave shot gather from the Landfill transect is shown in figure 4a. Several reflections are apparent, and the four strongest are marked. The reflection R4 appears to be from the top of the Intermediate 180-Foot Aquitard, although no well information exists to verify this interpretation. Reflections from at least the base of the FO-SVA are clearly visible in shot gathers along both transects, indicating that data quality is overall quite good.

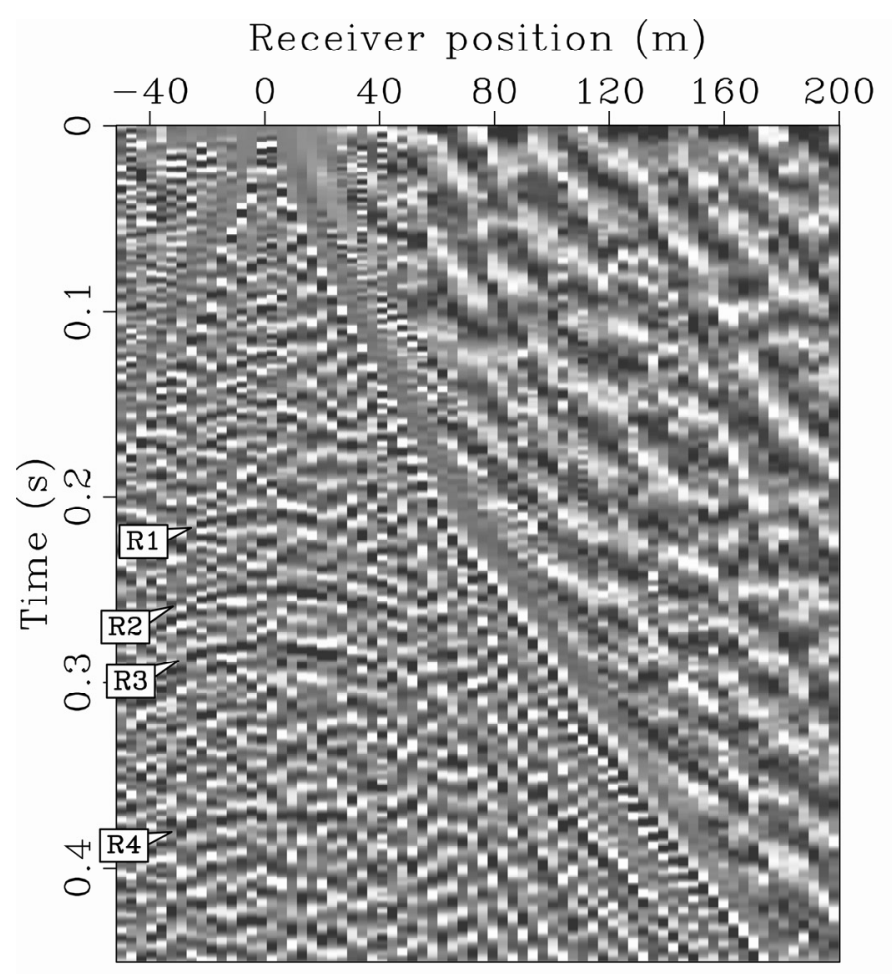

(a) Shear Waves

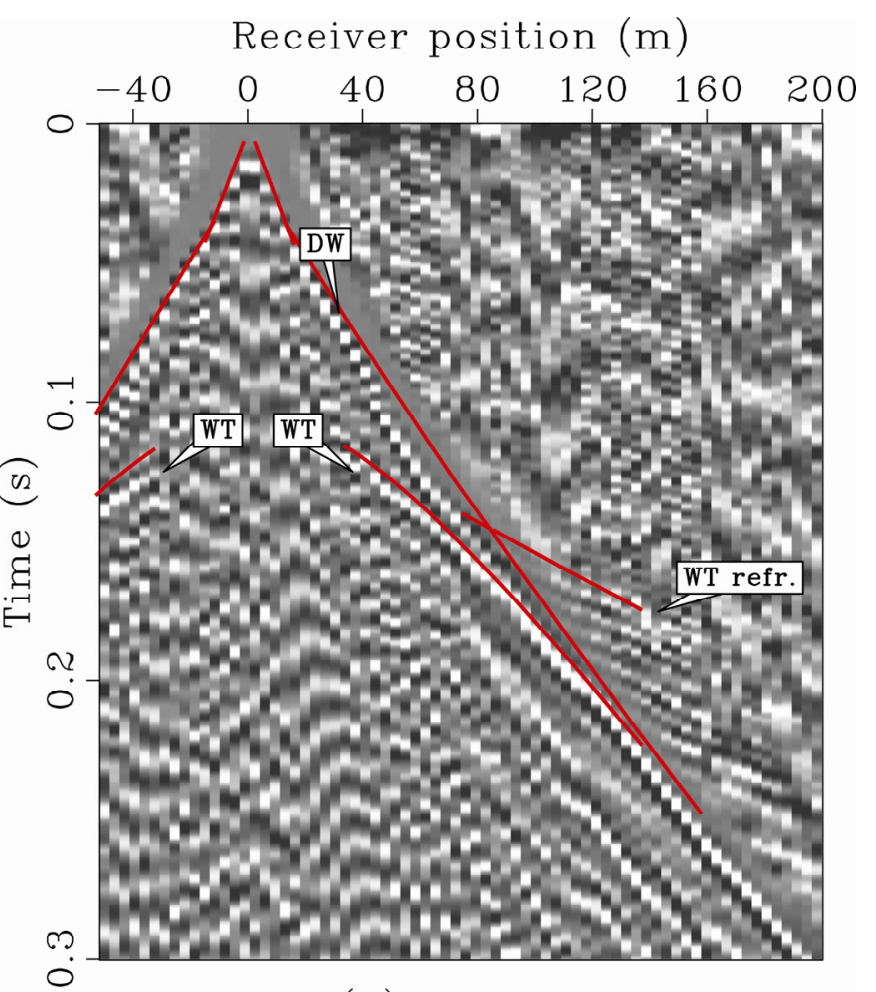

(b) P Waves

Figure 4. Shot gathers from Landfill transect. a) Shear wave data, with 4 reflections marked. R1 is from the top of the Fort Ord-Salinas Valley Aquitard(FO-SVA), R2 is from an interface within the FO-SVA, R3 is from the base of the FO-SVA, and R4 is from the top of the Intermediate 180-Foot Aquitard. b) P wave data, with the water table reflection (WT) and refraction (WT refr.) marked. The reflection is obscured by surface waves at near offsets. Red lines show arrival times for the direct wave (DW), the water table reflection, and the water table refraction predicted by numerical modeling. 


\section{Data Processing}

In order to produce seismic reflection images, we processed the shear wave data using the processing flow shown in table 2.

Table 2. Seismic data processing flow.

\begin{tabular}{|c|c|c|}
\hline Processing Step & Purpose & Comments \\
\hline $\begin{array}{l}\text { Stack data from separately recorded } \\
\text { hammer impacts }\end{array}$ & Create shot gather for each shot point & $\begin{array}{l}\text { In-office stacking allows for quality } \\
\text { control }\end{array}$ \\
\hline Apply elevation statics & $\begin{array}{l}\text { Account for elevation changes along } \\
\text { transect }\end{array}$ & Not necessary along Landfill transect \\
\hline $\begin{array}{l}\text { Sort to common mid-point (CMP) } \\
\text { gathers }\end{array}$ & $\begin{array}{l}\text { Arrange data by reflection point, for } \\
\text { stacking }\end{array}$ & \\
\hline $\begin{array}{l}\text { Apply frequency-wavenumber }(f-k) \\
\text { filtering }\end{array}$ & Remove surface wave energy & $\begin{array}{l}\text { Has only minimal effect on final } \\
\text { images, but facilitates velocity } \\
\text { analysis }\end{array}$ \\
\hline Conduct velocity analysis & Determine stacking velocities & $\begin{array}{l}\text { Conducted using constant-velocity } \\
\text { NMO-corrected CMP panels. }\end{array}$ \\
\hline $\begin{array}{l}\text { Apply normal moveout (NMO) } \\
\text { correction }\end{array}$ & $\begin{array}{l}\text { Flatten reflectors in preparation for } \\
\text { stacking }\end{array}$ & \\
\hline Apply top mutes & $\begin{array}{l}\text { Remove surface wave and refraction } \\
\text { energy, and reflections over- } \\
\text { stretched by NMO correction }\end{array}$ & \\
\hline Stack CMP gathers & Create one trace per CMP & $\begin{array}{l}\text { In addition to being essential to create } \\
\text { a seismic image, stacking is the most } \\
\text { effective signal/noise separation } \\
\text { technique }\end{array}$ \\
\hline $\begin{array}{l}\text { Apply minimum-phase Butterworth } \\
\text { bandpass filtering }\end{array}$ & $\begin{array}{l}\text { Minimize high- and low-frequency } \\
\text { noise }\end{array}$ & 15 or 20 to 100 or $120 \mathrm{~Hz}$ \\
\hline Apply lateral smoothing & $\begin{array}{l}\text { Enhance coherent reflections, } \\
\text { minimize noise }\end{array}$ & Option, but valuable \\
\hline Apply automatic gain control (AGC) & Equalize amplitudes & Largely for display purposes \\
\hline Apply depth conversion & $\begin{array}{l}\text { Convert vertical axis from time to } \\
\text { depth }\end{array}$ & $\begin{array}{l}\text { Using laterally-averaged NMO } \\
\text { velocities }\end{array}$ \\
\hline
\end{tabular}

This is a typical, basic, seismic reflection processing flow (see, for example, Yilmaz, 2001, p. 90-150). We have tested a number of more sophisticated processing steps, most notably the surface consistent statics algorithm described by Ronen and Claerbout (1985). However, we do not find that any of these more sophisticated processing steps significantly improve the images. We present those images that represent our best results in terms of both reflector clarity and interpretation confidence. The presence of obvious reflections in the shot gathers facilitates data processing, particularly velocity analysis, and also builds confidence in the resulting images. Because the data show little lateral heterogeneity, the choice of depth-conversion methods is appropriate and migration is unnecessary.

\section{Shear Wave Images}

The shear wave seismic reflection images in figures 5 and 6 show coherent reflections corresponding with the interfaces between the major aquifers and aquitards. In both figures, part (a) is the time section, and part (b) is a depth section, with depth conversion performed as described above. 
Simplified well log information is shown for the boreholes adjacent to each transect. Fit between the seismic data and the well information is quite good.
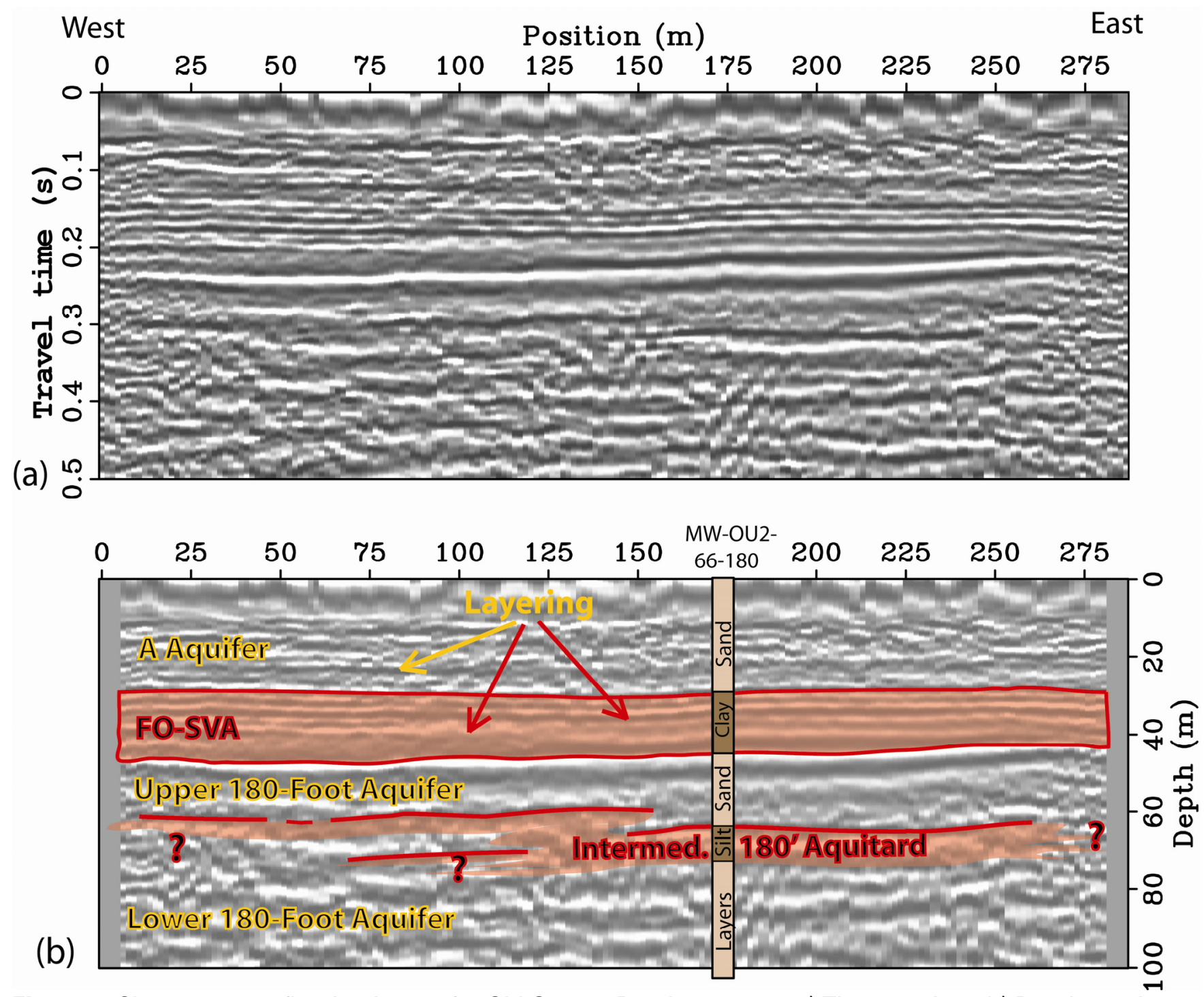

Figure 5. Shear wave reflection image for Old County Road transect. a) Time section. b) Depth section, with borehole information and interpretations overlain. Depth is relative to ground surface elevation of $45 \mathrm{~m}$ above sea level. 

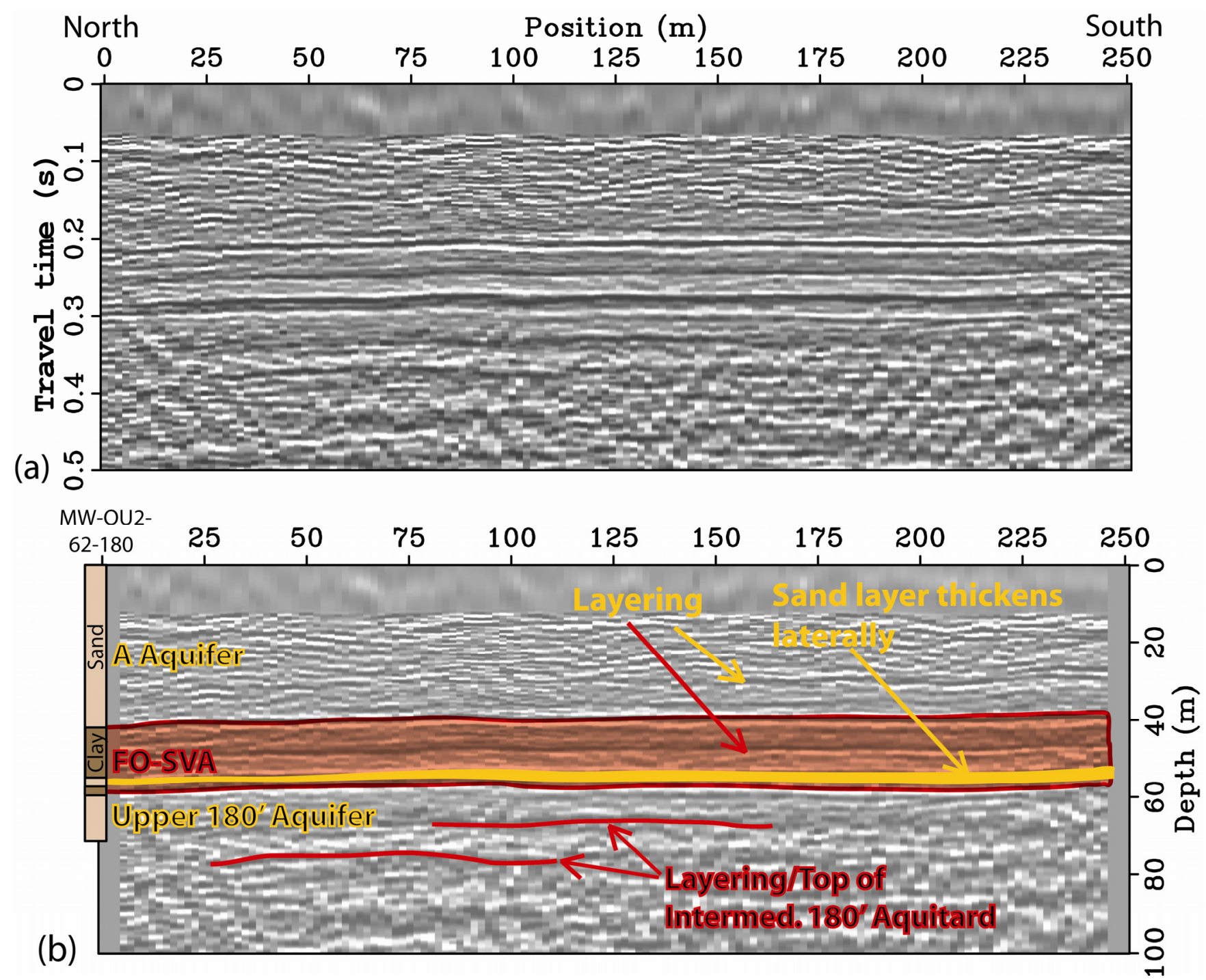

Figure 6. Shear wave reflection image for Landfill transect. a) Time section. b) Depth section, with borehole information and interpretations overlain. Depth is relative to ground surface elevation of $66 \mathrm{~m}$ above sea level.

Starting from the surface, both images show reflectivity within the A Aquifer corresponding with compositional stratigraphy in that layer. Both images clearly show the top and bottom of the FOSVA, along with layering within it. Reflections from within the FO-SVA likely correspond with the minor compositional changes that are identified in the driller's logs. The pattern of reflectivity from the base of the FO-SVA is particularly interesting. Along the Landfill transect (fig. 6), several reflection arrivals occur very close together at a time corresponding with the base of the FO-SVA. Borehole information from well MW-OU2-62-180 shows a 3.4-m thick sand layer that is $3 \mathrm{~m}$ above the base of the FO-SVA. The interlayering of clay/sand/clay is almost certainly responsible for the observed reflectivity pattern. This reflectivity pattern broadens in time (depth) to the south along the transect, and the individual reflections can be separately observed. We interpret that this reflectivity pattern represents the southward thickening of either the sand layer or the basal clay layer. Along the Old County Road transect, the reflection pattern corresponding with the base of the FO-SVA is different; the interface is seen as a single, low-frequency reflection. Borehole information shows a set of very thin 
layers at the base of the FO-SVA. Thus, we interpret that the reflections from the many thin layers interfere to result in a single broad reflection. In this case, the relatively high amplitude of the reflection would be an example of tuning (for example, Yilmaz, 2001).

In well MW-OU2-66-180 the Intermediate 180-Foot Aquitard is an 8-m silt layer, and the upper surface of this aquitard is visible as a clear reflection in the image between $160 \mathrm{~m}$ and $260 \mathrm{~m}$ horizontal position (fig. 5). Wells located off the ends of this transect show the aquitard as a set of very thin layers of silt, sand, and clay. In the image, evidence of the aquitard is not as clear at the ends of the transect as it is at the center. The lateral progression of the aquitard from a single homogeneous layer to a set of thin layers is likely responsible for the absence of, or faint appearance of, the reflection at the ends of the transect. In well MW-OU2-66-180, the base of the Intermediate 180-Foot Aquitard is not a clearly defined interface. Instead, the clay content decreases with depth, and numerous thin layers of silty and clayey gravel and sand represent the transition between the Intermediate 180-Foot Aquitard and the Lower 180-Foot Aquifer. Whether the lack of a clear reflection from the base of the Intermediate 180Foot Aquitard is due to the lack of a distinct interface, or simply to insufficient seismic energy penetration, is unclear.

The borehole adjacent to the Landfill survey transect extends only to a depth of $72 \mathrm{~m}$, which is above the Intermediate 180-Foot Aquitard (fig. 6). No other nearby wells extend deeper, so we lack independent information about the deeper part of the reflection section. The clear reflection at a depth of approximately $75 \mathrm{~m}$ between horizontal positions 25 and $112 \mathrm{~m}$ is likely the expression of the Intermediate 180-Foot Aquitard. However, without well information, this reflection can not be interpreted with certainty. A separate reflection, at a depth of approximately $65 \mathrm{~m}$ and visible between 75 and $150 \mathrm{~m}$ horizontal position, may also be the Intermediate 180-Foot Aquitard or may be a layer within the Upper 180-Foot Aquifer. These aquifers and aquitards are not very distinct from one another at all locations, and some well logs show them to consist of many layers of various compositions.

\section{P-Wave Surveys}

We conducted P-wave surveys along the same two transects that were used for the shear wave surveys, and we used the same acquisition geometries (table 1). We created the $\mathrm{P}$ waves using the weight drop source in its vertical-impact position for the Old County Road transect and using a sledgehammer impacting a steel plate for the Landfill transect. In the P-wave data (for example, the shot gather shown in fig. 4b), only one reflection is apparent. In order to determine whether this reflection is from the water table (at a depth of $33 \mathrm{~m}$ for the data in fig. 4b) or from the top of the FOSVA (at a depth of $42 \mathrm{~m}$ ), we conducted forward and inverse modeling using the methods described by Zelt and Smith (1992). Because the geology is nearly one-dimensional, we picked arrival times for only 5 shots interspersed along the Landfill transect; the arrival times are for the direct wave, the reflected wave, and the refracted wave associated with the reflected wave (see fig. 4b). Inverting simultaneously for velocity and layer boundary positions, we determined that the reflection is due to an interface at 33 $\mathrm{m}$ depth. We interpret that this interface is the water table, not the top of the FO-SVA. Some P-wave shot gathers, particularly along the Old County Road transect, show a second reflector. With twice the travel time of the water table reflection and opposite polarity, it is almost certainly the first multiple reflection of the water table.

Although the P-wave data do not include any reflections of interest, the water table refraction does have an interesting character. As can be seen in figure $4 \mathrm{~b}$, the initial onset of the water table refraction is diffuse, and it has a very reverberatory appearance. As Bradford and others (1998) point out, a thin embedded layer (high-velocity in their case) can trap seismic energy, resulting in arrivals with a reverberatory character. For these Fort Ord data, the embedded layer could be the saturated 
portion of the A Aquifer, which is beneath the unsaturated portion of the A Aquifer and above the FOSVA.

\section{Discussion and Conclusions}

The shear wave reflection method is favorable for imaging stratigraphy at the former Fort Ord because shear waves are very sensitive to compositional contrasts such as the interfaces between the sand aquifers and clay aquitards. In contrast to $\mathrm{P}$ waves, shear waves are largely insensitive to pore fluids, and thus are not affected by the deep water table at the site. The shear-wave reflection method provides good images of aquifer stratigraphy to a depth of at least $60 \mathrm{~m}$. The shear-wave images presented here provide the thickness of the A Aquifer and FO-SVA along the survey transects and indicate that there is only minor lateral variation within these layers. The images suggest that the Intermediate 180-Foot Aquitard shows greater lateral heterogeneity than do the overlying layers, in agreement with available borehole information. The images also provide specific information regarding the locations of heterogeneities in the Intermediate 180-Foot Aquitard. All of this information can provide valuable constraints for hydrogeological modeling. Because the Intermediate 180-Foot Aquitard may be coherent enough to prevent water flow even in locations where it is composed of layers too thin to image, results such as these would tend to overestimate the size of the hole in the aquitard. The difficulty of imaging thin layers, which is more pronounced for deep targets, is one that this method shares with virtually all geophysical methods.

The P-wave reflection method (at least as it was carried out in the present study) cannot effectively image aquifer stratigraphy at the former Fort Ord due to the strong reflection from the water table. Because any lithologic reflections are much weaker than the water table reflection, they are masked by it. Also, the strong impedence contrast of the water table traps much of the seismic energy above this reflector, leaving very little energy to image deeper layers. This phenomenon has been observed at other sites (for example, Goforth and Hayward, 1992): the reflection coefficient of the water table is significantly greater than that of the target, making the target nearly "invisible". A previous Pwave reflection study conducted elsewhere at the former Fort Ord was able to image the top of the FOSVA using a higher-frequency source (a seis-gun fired $0.6 \mathrm{~m}$ below the surface), but the energy could not penetrate to deeper layers (Merey and others, 1992).

Our P-wave data are an example where correct interpretation of the data is best achieved through combined inversion of reflected and direct/refracted arrival times (for example, Zelt and Smith, 1992). Because the water table refraction is reverberatory, its arrival time is difficult to pick on many shot gathers. But combined with the easily-pickable reflection arrival, the first break picks yield a selfconsistent velocity model that fits with the known geology and water table depth. Inversion of only first break picks, without the reflection picks, does not yield such a clear result.

\section{Recommendations for Future Work}

Based on the results of this study, future seismic reflection studies should be limited to only shear waves because the P-wave data do not provide useful information regarding aquifer stratigraphy. In order to maximize their value, future survey transects should be longer than those in this pilot study, as long as $1000 \mathrm{~m}$ or more. If possible, each transect should be positioned to pass near multiple boreholes and to intersect other survey transects. Such surveys will provide an improved understanding of regional trends (stratigraphic continuity versus layer pinch-outs, etc.), characterizing areas between boreholes and extending this information into areas where boreholes do not exist. The geophone spacings used in the present study were optimal for providing good data quality even for shallow layers. A wider geophone spacing could be used for future surveys, particularly if information on the shallower 
layers is not considered essential to the work. Wider spacings would speed data collection and reduce associated costs.

Seismic surveys are generally conducted along straight-line transects, though intersecting straight-line surveys could be conducted along a jagged transect. Though it would be possible to conduct a survey without vehicle access to the transect, logistics and efficiency would be significantly reduced. In addition, problematic surface waves are minimized by working on the compacted soils of roadways, resulting in better data quality. Ideally, future surveys would be conducted along developed routes, whether out-of-use dirt roads such as the Old County Road, sidewalks, pathways, or streets. Any surveys extending into the undeveloped area northeast of Abrams Road will likely require the clearing of brush in order to create a straight-line transect along which to work. The same is true for any surveys in the Fort Ord Natural Reserve (a part of the University of California Natural Reserve System) that surrounds the Old County Road. Future survey transects must be positioned according to the aforementioned criteria and also according to the needs of the hydrogeologists studying the site. The identification of suitable transect locations will be a key step toward establishing the value and feasibility of larger-scale seismic surveying.

This pilot study shows that the primary survey target is nearly at the limit of resolution of the shear-wave reflection methods employed for this study. Thus, future shear wave reflection studies must employ equal, or preferably improved, data acquisition techniques in order to ensure an equal or improved signal-to-noise ratio. Though noise levels could perhaps be reduced by nighttime data collection or other means, seismic signal improvement is the more promising way to improve the data signal-to-noise ratio. One obvious signal improvement would be the use of a more powerful seismic source, such as a vibrator similar to the IVI MiniVib. In addition to providing more total energy than a sledgehammer, a vibrator would use a swept signal that would help to overcome cultural noise and would also result in a higher frequency (higher resolution) seismic wavelet. Other possible seismic sources include accelerated weight drops; however, our results using such a source (see fig. 3) are not promising. An improved weight drop source could prove useful, but testing at Fort Ord is not justified unless a more effective source is definitively identified elsewhere. The sledgehammer proved effective in the pilot study, and could be the best option for future surveys if a vibratory or weight-drop source is unavailable. If a sledgehammer is used, it is essential that the signal-to-noise ratio be maintained as high as possible through careful survey design and execution.

The only other geophysical method that could provide useful information regarding the Intermediate 180-Foot Aquitard is the time domain electromagnetic sounding method (TDEM). This method will have difficulty imaging the layer of interest where it is a set of thin layers, but may be able to detect the layer where it is a thick coherent unit, providing lateral resolution on the order of $50 \mathrm{~m}$. The first step toward applying the TDEM method to the site on a large scale would be the calculation of numerical or analytical models to better assess the chances of success, and then, if warranted, to conduct a small TDEM pilot study at the site.

\section{Acknowledgments}

This work was conducted as a cooperative venture between the USGS, the U.S. Army Corps of Engineers (USACE) and the Army Base Realignment and Closure Program (BRAC). David Eisen (USACE liaison with BRAC) coordinated the BRAC side of the project and was an essential contributor to all phases of the work. Support was provided by BRAC and by the USGS Mendenhall Postdoctoral Fellowship Program. The authors are grateful to Paul Wigton for invaluable assistance with field data collection and equipment maintenance and repair. Karl Ellefsen and Mike Powers have provided valuable guidance from the inception through completion of this project. This manuscript has been improved by the careful reviews of Karl Ellefsen and Jeff Lucius. 


\section{References Cited}

Bradford, J., Sawyer, D., Zelt, C., and Oldow, J., 1998, Imaging a shallow aquifer in temperate glacial sediments using seismic reflection profiling with DMO processing: Geophysics, v. 63, p. 1248-1256.

Goforth, T., and Hayward, C., 1992, Seismic reflection investigations of a bedrock surface buried under alluvium: Geophysics, v. 57, p. 1217-1227.

Haines, S., and Ellefsen, K., 2006, Aquifer characterization with seismic shear wave reflection profiling: Proceedings, Symposium on the Application of Geophysics to Environmental and Engineering Problems, Environmental and Engineering Geophysical Society.

MACTEC Engineering and Consulting, Inc., 2005, Operable unit carbon tetrachloride plume groundwater remedial investigation/feasibility study, former Fort Ord, California Volume 1 Remedial Investigation: Final draft report prepared for the US Army Corps of Engineers.

Merey, C., Miller, R., Ticken, E., and Lewis, J., 1992, Hydrogeologic characterization using a shallow seismic reflection survey at Fort Ord, California: $62^{\text {nd }}$ Annual International Meeting, SEG, Expanded Abstracts, p. 370-373.

Ronen, J., and Claerbout, J., 1985, Surface-consistent residual statics estimation by stack-power maximization: Geophysics, v. 50, p. 2759-2767.

Yilmaz, O., 2001, Seismic data analysis: Society of Exploration Geophysicists.

Zelt, C., and Smith, R., 1992, Seismic travel time inversion for 2-D crustal velocity structure: Geophysical Journal International, v. 108, p. 16-34. 